\title{
Right to be Present and Presumption of Innocence in Cyprus Law
}

\author{
NIKITAS HATZIMIHAIL
}

\begin{abstract}
This Report studies the legal status of persons suspected and accused of committing a crime in the light of Directive 2016/343/EU and its implementation in 2018 into Cyprus law, that is with regard their rights to silence and not to incriminate themselves, the scope of the presumption of innocence and their right to be present and the regulation of trials in absentia. It is noted that Cyprus criminal procedure follows the English common law legal tradition, which adopts the system of adversarial criminal trial and places strong emphasis on the accused being present in order for the Court to obtain jurisdiction over an accused person. The European Convention on Human Rights discourse has also had a very strong influence on the Cyprus constitution and case law. The strong connection of the rights discussed, which are seen as emanating from the presumption of innocence and the principle of fair trial, must also be noted. In 2018, Cyprus introduced new general provisions on the right to silence and not to incriminate oneself, which replicate the Directive's provisions but also affirm constitutional principles elaborated by the case law of the Supreme Court of Cyprus and supported by the European Convention on Human Rights. With regard to trials in absentia, it was decided that the existing common-law regime may actually be more protective of accused persons than a more formal legislative system and thus serve better the purpose of the Directive.
\end{abstract}

Keywords: • right to be present $\bullet$ presumption of inocence $\bullet$ common-law regime - Cyprus

Correspondence Address: Nikitas Hatzimihail, University of Cyprus, Department of Law, Archiepiskopou Kyprianou 30, Limassol 3036, Cyprus, email: nikitas.hatyimihail@ucy.ac.cy.

https://doi.org/10.4335/978-961-6842-96-9.1-21

ISBN 978-961-6842-96-9 (pdf) 


\section{Introduction}

From the point of view of comparative law, Cyprus is a mixed legal system in the sense that both major European legal traditions co-exist, each in control of specific legal fields (Hatzimihail, 2013). Unlike other mixed legal systems, in Cyprus the English common law tradition dominates the core subjects of private law (including contracts and torts), as well as criminal law and procedural law across the board (Hatzimihail, 2015). For the purposes of this study, Cyprus should be regarded as a common-law jurisdiction.

The common-law background (and orientation) of the criminal justice system is an important reason why a study of Cyprus can contribute a distinct perspective to the PRESENT project. This is so especially if one considers the very rich Anglo-American case law on matters pertaining to the presumption of innocence, the right to silence and not to incriminate oneself and on the right of the accused to be present and be effectively heard at court. Another reason lies in the relatively small size of the jurisdiction, which allows a more comprehensive view of how the norms in question actually operate (Hatzimihail, 2017). On the other hand, this small size, together with the relatively undeveloped doctrinal discussion, present certain challenges for both doctrinal and empirical research into Cyprus criminal procedure law and practice. This realisation also helps underline the importance of PRESENT research on Cyprus: in evaluating the preimplementation state of affairs and in tracing the potential influence of the implementing legislation on Cyprus legal practice, there is a contribution to be made to both better understanding and reforming the administration of criminal justice in the island and to fulfilling the objectives underlying the broader European Area of Justice, Freedom and Security and especially Directive 2016/343.

The purpose of this country report is to present and evaluate the state of play in Cyprus law and the criminal justice system with regard to the treatment of persons suspected and accused of committing a crime. This entails, on the one hand, a study of the law immediately prior to the introduction of Directive 2016/343 into the Cyprus legal system and, on the other hand, an evaluation of the changes that have possibly been brought- or are expected to be brought - by the Directive and its national implementation. As will be seen, the Directive was implemented only very recently and the short-term changes it has ushered in are minimal.

This is essentially a doctrinal study that takes due account of the results of empirical research conducted and material consulted. Section 2 provides the context necessary for understanding Cyprus law. The state of affairs prior to the implementation of the Directive is described in Sections 3 and 4, regarding the presumption of innocence and the right to be present respectively. Section 5 presents the actual legislative implementation of the Directive, the policy debates during the implementation process and speculates about long-term trends. 
Enchancing the Right to be Present

N. Hatzimihail: Right to be Present and Presumption of Innocence in Cyprus Law

\section{The Context}

The emphasis of this Study is on doctrinal analysis, with due consideration of the results of the empirical research conducted and material consulted. It is imperative therefore to first explain in more detail the theory and operation of sources of Cyprus law, before proceeding with consideration of the remaining material. Prior to that, however, the basic features of the Cyprus criminal justice system must be outlined.

\subsection{Criminal Processes in Cyprus}

Cyprus has a two-instance judicial system. At the trial level, criminal jurisdiction vests either the District Court (a single judge sitting) for less serious offenses or the Assizes

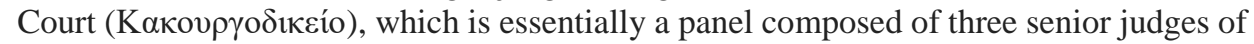
the District Court for felonies. On the contrary there is no jury system or any kind of lay participation in criminal justice.

Arts 20 and 24 of the Courts of Justice Law 1960 define the jurisdiction, for criminal cases, of the Assizes Court and the District Court respectively. The Assizes Court is conceptually the principal criminal court, even though it adjudicates only serious cases, essentially felonies. According to Art. 24, the criminal jurisdiction of the District Court as such, i.e. in single-judge bench, to "judge summarily all offenses punishable with imprisonment for a term not exceeding five years or with a fine not exceeding fifty thousand [Cyprus] pounds" i.e. approximately $€ 80.000$. The term comes from the colonial-era legislation, where jurisdiction was limited to even pettier offenses (e.g. imprisonment of up to a year).

Appeals to the Supreme Court are allowed in all cases (Art 25(2) of the Courts of Justice Law 1960), with no leave to appeal required (unlike some common-law jurisdictions; Cyprus court costs are also relatively low, again unlike some common-law jurisdictions). Even though the Supreme Court is primarily a common-law appellate court, focused on questions of law, it has the ability even to review facts and rehear evidence (Art. 25(3): ".. the Supreme Court ... shall not be bound by any determinations on questions of fact made by the trial court and shall have power to review the whole evidence, draw its own inferences, hear or receive further evidence and, where the circumstances of the case so require, re-hear any witnesses already heard by the trial court, and may give any judgment or make any order which the circumstances of the case may justify").

Cyprus criminal process follow the system of adversarial criminal trial. Cyprus has a body of full-time professional prosecutors, consisting of government lawyers working within the Law Office of the Republic (Kyprianou, 2010). The Attorney-General of the Republic is the head of the Law Office and has the final say over all prosecutions. Cyprus has a unitary Police force, whose roots go back to the colonial era and whose scope even extends to fire-brigade and coastguard duties (unlike other Southern European countries who have separate police forces for cities or the countryside). Police handles all 
investigations - there is no institution of investigating magistrates - and even prosecutions of petty offenses.

\subsection{Sources of Cyprus Criminal Law}

Cyprus criminal law and procedure follow the English common law tradition(Papacharalambous, 2015; Hatzimihail, 2013). The starting point however for both substantive and procedural criminal law consists of "codes" - colonial-era legislation seen as codifying the English common law and interpreted in accordance with the evolving English case law. In the case of criminal procedure, the paramount source is

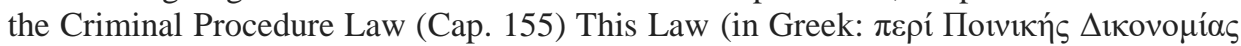

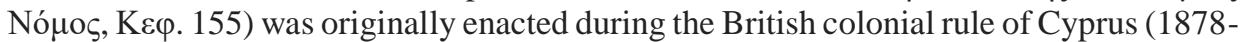
1960), taking its essential form by 1948 with subsequent modifications to this day. Most of its fundamental provisions dealt with below have remained intact, although some modifications have been made, as noted in the appropriate point in our text. Compared to a Continental Code of Criminal Procedure, the Criminal Procedure Law does not contain a "general part" or expressly states principles - the first such express principles were in fact only added, in the very beginning of the Law, by the legislation implementing Directive 2016/343 in 2018. The Law has however survived, with the necessary adjustments, to this day. It is clearly oriented towards judges, legal practitioners and police officers with an eye for leaving some discretion to the judge, as is common in the common-law tradition. As will be seen, in some cases such discretion has allowed the system to operate effectively in the interests of the accused. ${ }^{1}$

The other important piece of legislation for our subject is the Rights of Suspect Persons, Arrested Persons and Persons Held in Custody Law 2005. The Law was originally enacted as the Rights of Arrested Persons and Persons Held in Custody Law; it was amended in 2014 and 2017 in order to implement Directives 2012/13 and 2013/48. The reference to "Suspect Persons" in its summary title was actually added by the legislation implementing Directive 2016/343.

The other major source of written law is the Constitution of the Republic of Cyprus (1960). The Constitution includes a chapter on the bill of rights, whose provisions are influenced by or often replicate the provisions of the European Convention on Human Rights. This is notably the case with regard to Articles 11-12 and 30 of the Constitution which correspond (in this order) to Articles 5, 7 and 6 of the Convention. Both the Constitution and the European Convention have higher legal force than legislation. But the influence of both is deeper than simply as a control mechanism of legislative excesses.

\footnotetext{
${ }^{1}$ See in Section V below the argument made (including notably by the Supreme Court) in the legislative discussion about implementing the Directive, i.e. that under the existing system where the judge simply has discretion to proceed with the trial in the absence of the accused, such discretion is less likely to be exercised for a trial in absentia than in a more formal system with conditions.
} 
In the absence of general principles expressly pronounced in the colonial-era (or subsequent) legislation, but also the lack of influential scholarly publications, the Constitution has become an integral part of the criminal justice discourse in its core. Constitutional doctrine with regard to fundamental rights has been built upon ECHR doctrine and case law.

Case law is an important element of this system, and references to case law abound in the following pages. It must be noted that, even though Cyprus criminal procedure falls squarely within the English legal tradition, references to English case law are reserved for specific, novel or controversial cases (unlike other fields shaped by English common law, such as contracts and commercial law), and this explains why English reference works were not used more in this report. In contrast to this, a body of Cyprus appellate case law has been developed by the Supreme Court - sitting either as criminal appeals court or as a constitutional court - since independence. This case law interprets the Criminal Procedure Law and examines the practices of police and lower courts. It has also elucidated the constitutional provisions pertinent to the subject.

\subsection{Distinctive features of the common-law tradition in criminal trials}

It is very important to note that the Cyprus criminal justice system, being a creature of the common-law tradition, is grounded upon the adversarial model of criminal trial. Compared to a continental system following the inquisitorial model of criminal trial, the adversarial one places an even more important role in having the accused person present his or her own case, with the help of a qualified legal counsel (Langbein, 2003). One may argue either that the adversarial system better protects the rights of the defendant or, quite the contrary, that there is no distinction between investigators and the prosecution. It is true that, compared to a Continental inquisitorial process, there are fewer procedural stages between investigation and trial at court, but there are equivalent mechanisms for disposing of cases, by granting prosecution considerable leeway in deciding whether to prosecute. For better or for worse, there is no fiction of a neutral prosecutor - even the architecture of the court room on the one hand points to direct opposition between prosecution and defense and on the other hand elevates the accused person to the status of opposing party vis-à-vis the prosecution. For such a system to work, it is even more important than in an inquisitorial system for the accused to be present at trial and to be able to present his or her case. This explains in part the reluctance of common-law courts, and more specifically Cyprus courts, to try a case in absentia.

Another conceptual reason for this reluctance is that common law doctrines on jurisdiction have remained more attached to traditional notions about obtaining jurisdiction, according to which the court had to physically obtain jurisdiction over the defendant, notably by serving to the defendant in person the summons. Service of summons is thus paramount for obtaining jurisdiction, rather than a technical means of ensuring that defendants are informed of the case against them. 


\subsection{Fundamental principles}

The right to fair trial is explicitly protected by Article 30 of the Constitution in terms virtually identical to Article 6 of the European Convention on Human Rights (Paraskeva, 2015).

Moreover, Article 12 of the Constitution, which corresponds to Article 7 of the European Convention on Human Rights, is dedicated to the rights of the accused. Article 12(5) essentially sets out procedural safeguards that correspond to the spirit of the principle of fair trial. Article 12(4) consecrates the presumption of innocence. As will be elaborated below, other fundamental principles and rights, such as the right to silence and the right not to incriminate oneself are regarded as deriving from the principle of presumption of innocence. In a sense, these rights are interconnected but they also have their distinct identity, something that will become even more apparent now that both right to silence and right not to incriminate oneself are governed by distinct legislative provisions in the Criminal Procedure Law.

\subsection{Procedural position of suspect and accused}

Despite the penchant of the English legal tradition for legislative definitions, no express statutory definition of what constitutes either a "suspect" or an "accused" may be found in the Constitution or legislation. This actually makes sense: in practice, the very nature of labelling someone as a suspect is an early, fluid step in the criminal process: it first comes into being in the mind of the police investigator, before it is externalised into speech, but things are fluid until that moment.

Effectively, however, we can determine what is a suspect person in Cyprus law by a closer look to the provisions on criminal arrest, i.e. Articles $9 \mathrm{ff}$. of the Criminal Procedure Law. The criterion appears to be reasonable suspicion, whether for an arrest without a warrant or for the issue of an arrest warrant.

In the former case, an arrest may be made by either a police officer or even an individual who "suspects upon reasonable grounds" or "reasonably suspects" the person arrested of having committed an offense, provided certain other conditions are also met (Art. 14 and 15). There is also the possibility of arrest of any person who commits an offense in the presence of the arresting police officer, private person or Judge (Arts. 14, 15 and 16 respectively). In that case, reasonable suspicion has been elevated to certainty. These provisions have remained unchanged since the colonial era and derive directly from the common law.

In the latter case, the judge must be "satisfied" by a written affidavit that "reasonable suspicion" exists that the person has committed an offense (or else if such arrest is 
necessary to prevent an offense from being committed, or an escape). (Art. 18). The "reasonable suspicion" clause was inserted by L. 10(I)/1996. Under the original colonialera provision, the criterion was simply whether the judge "considers that such warrant is necessary or desirable."

Case law has elaborated on the meaning of "reasonable suspicion." Suspicion must be genuine and not used for other purposes (Merthodja v. Police, 1987; Parpas v. Republic 1988; Stamataris v Police, 1983). It must also be reasonable, in the sense that it emanates from - and is justified by - the evidence in possession of the Police (Stamataris v Police, 1983). Suspicion must also appear truthful, in the sense that the evidence on which prosecution relies for its case must be sufficient for an objective observer to be convinced that the specific suspect could have committed the specific offense (Nikolaides v Police, 1999).

The effective determination of what constitutes an accused person is clearer: a person is characterised as "accused" at the moment of formal indictment, i.e. when the "criminal

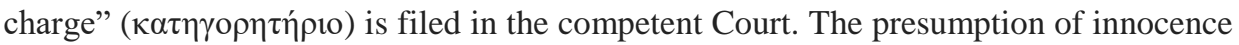
is obviously not affected, but, at that moment, the investigation has been completed and suspicion is converted into accusation.

The content of these concepts does not change during the process. Once reasonable suspicion is created, a person is a suspect and remains so until the conclusion of the investigation and the indictment when that person becomes the accused - and remains thus defined until the end of the trial. Even if convicted, the accused person who appeals his or her conviction remains the accused-appellant in the appellate process.

According to Article 24 of the Criminal Procedure Law, which dates back to the colonial period, a Court can only remand the arrested person in custody, in order to enable the investigation to be completed, for a period "not exceeding eight days at any one time". The Constitution in 1960 affirmed this rule and added further conditions: the person arrested must be brought before the judge within twenty-four hours from his arrest (Art. 11(5)); custody may not exceed three months in total and the judge must rule each time and her judgment is subject to appeal (Art. 11(6)).

The physical presence of the suspect is necessary (Charalambous v. The Police, 1974). Suspect must be present. It is unclear whether it is sufficient for the suspect's lawyer to appear in lieu of the suspect.

\subsection{Presumption of innocence}

The burden of proof for establishing guilt lies with the prosecution (Police v Chrysanthou; Costis Panayi Kefalos v. The Queen). 
No Cypriot authority exists on the temporal scope of the presumption of innocence, but it has been argued that the presumption extends to the appellate process. A judgment is supposed to have immediate effect (Art 47 of the Courts of Justice Law), but this does not necessarily mean that its effect can also negate the presumption. The European Court of Human Rights decision in Konstas v Greece, 2011 has been forcefully cited as authority in Cyprus courts. In a recent case, however, the full bench of the Supreme Court was split 6-6 as to whether to allow an appeal against a criminal conviction by the Assizes Court and let the conviction stand (Loizidis v Republic, 2014). A petition alleging violation of the presumption is currently pending before the European Court of Human Rights.

Presumption of innocence also informs the stance of courts in those instances where the accused is at court but the prosecutor fails to appear for some reason: the Court has discretionary power to dismiss the case and acquit the defendant, if it seems fit (Kyriakides v Lumian Ltd, 2000). This does not apply to the absence of witnesses for the prosecution (Attorney-General v Spanias, 1993)

\subsection{Right to silence and to not incriminate oneself}

Prior to the implementation of the Directive 2016/343, Cyprus law contained no express

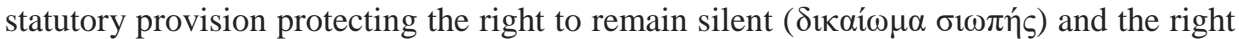
not to incriminate oneself ( entrenched in the criminal justice system. They were essentially elaborated by Cyprus case law, which built on the basis of both the constitutional discourse of fundamental rights and the English common-law tradition, which is strong on this point.

The Supreme Court has repeatedly held that both the right of silence, and the right not to incriminate oneself, derives from the principle of the presumption of innocence and lies at the core of the right to a fair trial (Republic v Avraamidou, 2004; Psyllas v Republic, 2003; President of the Republic v House of Representatives, 1994). The constitutionally prescribed right to freedom of speech and expression has also been invoked as an indirect safeguard of the right of silence, at least insofar it underlies statutory interpretation (Kirkos v Cyprus Securities Commission, 2006; Paraskeva, 2005). Courts have held that the right to silence or no self-incrimination does not extend over evidence that the accused has abandoned, such as in an ashtray (Yannidis v Police, 2002). But the right not to selfincriminate oneself extends over instances where the police used indirect means, such as offering the suspect a drink with a straw in order to involuntary obtain a DNA sample (Psyllas v Republic, 2003).

\section{The Right to be Present in Cyprus Law}

The right of the accused to be present at the trial is guaranteed by the Constitution in Article 11(2)(c) and Article 30(3), which replicate respectively the provisions of Article 5(1)(c) and Article 6(3) of the European Convention on Human Rights. These 
constitutional provisions notwithstanding, the right to be present was consecrated during the colonial era, in Article 63 of the Criminal Procedure Law, which remains in force, unchanged:

(1) The accused shall be entitled to be present at the Court during the whole of the trial so long as he conducts himself properly.

(2) If an accused does not conduct himself properly, the Court may, in its discretion, direct him to be removed and kept in custody and proceed with the trial in his absence making such provision as in its discretion appears sufficient for his being informed of what passed at the trial and for the making of his defence.

(3) The Court may, if it thinks proper, permit the accused to be out of Court during the whole or any part of the trial, on such terms as it may think fit.

Under Article 12(5) of the Constitution, the accused has the right to defend himself in court in person and exercise his rights to call and examine defense witnesses as well as cross examining the witnesses of the prosecution.

\subsection{Interrelation between the right to be present at trial and other fundamental human rights in Cyprus Law}

Cyprus courts must exercise due diligence in securing the presence of the accused by properly summoning him or her and they must take measures to discourage his unjustified absence from the hearing. While Article $6 \S 1$ (neither Article 12 or 30 of the Cyprus Constitution) cannot be construed as conferring on an applicant the right to obtain a specific form of service of court documents such as by registered post, in the interests of the administration of justice, the applicant should be notified of a court hearing in such a way as to not only have knowledge of the date, time and place of the hearing, but also to have enough time to prepare his or her case and to attend the court hearing (Korchagin v Russia, 2006, par. 65).

In Cyprus, the accused has the right to be present in his trial according to his constitutional rights on the basis of Articles 12 and 30 of the Constitution and Article 6 of the European Convention on Human Rights but, at the same time, the accused has also an obligation to attend the trial unless the Court has allowed him to be absent on the basis of sections 45(1) and 63(3) of the Criminal Procedure Law.

This issue was examined by the Supreme Court in Republic v. Demetriades (1973) where President Triantafyllides said, inter alia:

"In view of the fundamental rights of an accused person to have a fair trial in every respect, which is safeguarded by Article 30 of our Constitution - as well as by Article 6 of the European Convention on Human Rights, which was ratified by Cyprus by the European Convention on Human Rights (Ratification) Law, 1962, (Law 39/62) - we are of the opinion that, as is also expressly laid down in section 63 of CAP. 155, an accused person has a right to be present at his trial and, so long as he conducts himself properly, nobody can deprive him of such right. 
We are, further, of the opinion that (...) an accused person has, also, a duty to be present at his trial; and this duty is not incompatible with his aforesaid right to be present at his trial; and this duty is not incompatible with the aforesaid right to be present at his trial, because that right is a "right to be present" and not a "right to be or not to be present". Such duty arises not only because of the nature of the criminal trial - (which, being an essential process for the application of the criminal law, concerns the State and every citizen, and it not only a mere contest of private interests, as is a civil action) - but, also, by necessary inference from the provisions of section 63(3) of CAP.155, as well as from those of section 45(1) of the same Law regarding the power to "dispense with personal attendance of the accused" at a summary trial; as stated earlier on in this Decision, section 63 refers to both summary trials and trials on information, and so the said provisions of section 45(1) may properly be taken into account, in addition to those of section 63(3), in reaching our conclusion as to the duty of an accused person to be present at his trial (...)".

The principle of an oral and public hearing is particularly important in the criminal context, where a person charged with a criminal offence must generally be able to attend a hearing at first instance. Hence, at first instance, the concept of a fair trial means that a person charged with a criminal offence should be entitled to attend the hearing (Colozza v. Italy, 1985, par. 27-29).

Without being present, it is difficult to see how a defendant could exercise the specific rights set out in sub-paragraphs (c), (d) and (e) of paragraph 3 of Article 6 of the ECHR (which corresponds to Article 12 of the Cyprus Constitution), i.e., the right to "defend himself in person" (Article 12.5 (c) of the Constitution), "to examine or have examined witnesses" (Article 12.5 (d) of the Constitution) and "to have the free assistance of an interpreter if he cannot understand or speak the language used in court" (Article 12.5 (e) of the Constitution).

In the interests of a fair and just criminal process it is of capital importance that the accused should appear at his trial (Lala v The Netherlands, 1994; Lorenzo v Italy, 2004). The duty to guarantee the right of a criminal defendant to be present in the courtroom either during the original proceedings or in a retrial - ranks as one of the essential requirements of Article 6 (Stoichkov v. Bulgaria, 2005, par. 56).

Although this is not expressly mentioned in paragraph 1 of Article 6 (neither in Articles 12 and 30 of the Cyprus Constitution), the object and purpose of the Article taken as a whole show that a person "charged with a criminal offence" is entitled to take part in the hearing. Moreover, sub-paragraphs (c), (d) and (e) of paragraph 3 (which corresponds to sub-paragraphs (c), (d) and (e) of paragraph 5 of Article 12 of the Cyprus Constitution) guarantee to "everyone charged with a criminal offence" the right "to defend himself in person", "to examine or have examined witnesses" and "to have the free assistance of an 
interpreter if he cannot understand or speak the language used in court", and it is difficult to see how he could exercise these rights without being present (Colozza v. Italy, 1985). Moreover, the right to be present at the hearing allows the accused to verify the accuracy of his or her defence and to compare it with the statements of victims and witnesses (Medenica v. Switzerland, 2002, par. 54).

In the case of Sejdovic v. Italy, (2006) the European Court has held that where a person charged with a criminal offence had not been notified in person, it could not be inferred merely from one's status as a "fugitive", which was founded on a presumption with an insufficient factual basis, that the defendant had waived the right to appear at trial and defend oneself. Moreover, a person charged with a criminal offence must not be left with the burden of proving that he was not seeking to evade justice or that his absence was due to force majeure. At the same time, it is open to the national authorities to assess whether the accused showed good cause for his absence or whether there was anything in the case file to warrant finding that he had been absent for reasons beyond his control (Sejdovic $v$. Italy, 2006, par. 87).

In the case of Sanader v. Croatia (2015), the European Court held that the requirement that an individual tried in absentia, who had not had knowledge of his prosecution and of the charges against him or sought to evade trial or unequivocally waived his right to appear in court, had to appear before the domestic authorities and provide an address of residence during the criminal proceedings in order to be able to request a retrial, was disproportionate. This was particularly so because once the defendant is under the jurisdiction of the domestic authorities, he would be deprived of liberty on the basis of the conviction in absentia. In this regard, the Court stressed that there can be no question of an accused being obliged to surrender to custody in order to secure the right to be retried in conditions that comply with Article 6 of the Convention. It explained, however, that this did not call into question whether, in the fresh proceedings, the applicant's presence at the trial would have to be secured by ordering his detention on remand or by the application of other measures envisaged under the relevant domestic law. Such measures, if applicable, would need to have a different legal basis - that of a reasonable suspicion of the applicant having committed the crime at issue and the existence of "relevant and sufficient reasons" for his detention

Bail

Article 5(4) of the European Convention provides:

Everyone who is deprived of his liberty by arrest or detention shall be entitled to take proceedings by which the lawfulness of his detention shall be decided speedily by a court and his release ordered if the detention is not lawful.

Article 11(7) of the Cyprus Constitution provides:

Every person who is deprived of his liberty by arrest or detention shall be entitled to take proceedings by which the lawfulness of his detention shall be decided speedily by a court and his release ordered if the detention is not lawful. 
As it can be seen from the text of the two relevant paragraphs, their provisions are almost identical. Article 5(4) of the European Convention and Article $11 \S 7$ of the Cyprus Constitution, both generally require that a detained person or his legal representative be permitted to participate in an adversarial oral hearing (Allen v. United Kingdom, 2010), and the European Court has frequently found states in violation of the Convention where bail has been considered in the absence of both (for example: E.M.K. v. Bulgaria, 2005). The European Court has said that the judge determining bail "must himself or herself hear the detained person before taking the appropriate decision" (T.W. v. Malta, 1999), but this appears to mean the hearing of representations from the defendant or his lawyer, rather than hearing oral evidence.

If the proceedings are adversarial like in Cyprus then the defendant must know the nature of the prosecution objections to his release, and be given the opportunity to comment on them (Farhad Aliyev v. Azerbaijan, 2010). The representations made should be oral rather than in writing (Kotsaridis v. Greece, 2004), and a representative from the defence should be physically present to hear any representations made by the prosecution (Wloch $\mathrm{v}$. Poland, 2000).

The European Court in the case of Grauzinis v. Lithuania, (2000, par. 34) held that given what was at stake for the applicant, i.e. his liberty, as well as the lapse of time between the various decisions, and the re-assessment of the basis for the remand, the applicant's presence was required throughout the pre-trial remand hearings in order to be able to give satisfactory information and instructions to his counsel.

Equally, a right to be present could be established where the defendant relied on matters exclusively within her own knowledge, such as conditions of prison detention (Mamedova v. Russia, 2006) or where the case called for an assessment of the defendant's character, personality, predisposition to further offences or mental state (Duda v. Poland, 2006).

\subsection{Right to be present as a foundation of the jurisdictional rules}

Under Art. 46(1)(a) of the Criminal Procedure Law, summons addressed to an individual "shall be served either by delivering it to him personally or by leaving it with some adult person living with him or being in charge of the place in which he resides or of the place of his business or occupation."

The court may order the serving to be done with alternative means only if the primary way of serving described above is deemed impossible: this latter provision of Art. 46(1A) was only added by L. 42(I)/2014 to cover extreme cases but is used very sparingly. 


\subsection{A "functional right" (or obligation)}

So the right to be present also includes a negative right to be absent, which can only be exercised with the permission of the Court under Art. 45(1) or 63 of the Criminal Procedure Law. The accused can therefore not simply waive his right to be present, by informing the court that he simply would prefer not to be present at trial and he wishes to stay at home instead (Loizou \& Pikis, 1975, 79). The accused's claim to absolute freedom to be "out of Court" must be balanced against the public interest of ensuring a fair trial and having all sides presented before the court of law. In a recent case, Psara-Miltiadou J. spoke precisely of a dual nature (right and obligation) of the accused's right to be present (Gregoriou v Registration Board of Real Estate Agents, 2016). ${ }^{1}$ Likewise e.g. Georgiou v Fytoria Solomou Ltd (2015).

In such a case, a distinction must be drawn as to whether the accused is under custody or not. if the accused is not under custody, the Court "may issue either a summons or a warrant to compel the attendance of the accused before the Court," according to Art. 44(1) of the Criminal Procedure Law (Socratis, alias Kokkalos v. The Police, 1967). It is also possible that the accused be allowed by court order not to appear himself but be represented by counsel or even to respond in writing in accordance with Article 45(1).

If the accused is under custody but nonetheless refuses to present himself before the Court, the Court may continue the trial in his absence but should nonetheless "proceed as if there was entered a plea of not guilty, because, in view of the presumption of innocence, it is up to the prosecution to prove his guilt according to law" (Republic v. Nicos Demetriades, 1973). In such a case, it has been held that "it would be desirable to serve him with a copy of the charges so that he can have full knowledge of the offence or offences in respect of which he will be tried, and, also, to inform him of his right to be defended by counsel, as well as of his right to ask, in a proper case, for free legal assistance." (Republic v. Nicos Demetriades, 1973).

\subsection{Discretionary power}

The court has the discretionary power of the court to order the continuation of the process. In the words of Triantafyllides, P. in Republic v Demetriades (1973):

There exists express provision-subsection (3) of section 63-that a trial Court "may, if it thinks proper, permit the accused" to be out of Court during the whole or part of the trial; the part of subsection (3) which we have put in quotes shows that such subsection, when construed according to its natural meaning, envisages a situation in which the permission of the Court for the accused to be out of Court is sought by or on behalf of the accused on grounds which, when put forward, are found by the trial Court to be such as to render the granting of its permission a proper course in the circumstances, on such terms as it may think fit; it cannot, therefore, be said that under subsection (3) there can be dealt with every situation where the accused is absent from the trial and so it may become necessary, where subsection (3) is not found to be applicable, to resort to trial in the absence of the 
accused, in the exercise of the relevant inherent discretionary powers of the trial Court.

And further below:

"We are, therefore, of the opinion that the proper answer to question (b) is that when an accused, who is in custody and who is to be tried on information, is not in the dock at the commencement of his trial, because of his having persistently refused to attend and because the authorities concerned did not take measures to bring him to Court against his will, the trial Court may, by a verbal direction, order that the accused shall be brought up, and of course then the said authorities would have to implement such direction; but the Court may, also, in exceptional circumstances-even if they do not come within section 63(3)-decide, in the exercise of its inherent powers (see the Abrahams case, supra, referred to in the case of Jones,(supra), to proceed with the hearing in the absence of the accused, irrespective of whether or not he is represented by counsel. Our Criminal Procedure Law, Cap. 155, provides, expressly, for trial in the absence of the accused in relation only to certain summary cases-by section 89-but that, in view of section 3 of Cap. 155, does not exclude resorting to the aforesaid inherent powers.»

This notion of inherent discretionary power is drawn from the English common law. Republic v Demetriades, 1973 cites R v Jones, 1972 with further reference to R v Abrahams (1895). ${ }^{2}$

Such discretionary power is however exercised with great restraint. In the words of the English court in R v Jones, 1972:

Considerations of practical justice in my opinion support the existence of the discretion which the Court of Appeal held to exist. To appreciate this, it is only necessary to consider the hypothesis of a multi-defendant prosecution in which the return of a just verdict in relation to any and all defendants is dependent on their being jointly indicted and jointly tried. On the eve of the commencement of the trial, one defendant absconds. If the court has no discretion to begin the trial against that defendant in his absence, it faces an acute dilemma: either the whole trial must be delayed until the absent defendant is apprehended, an event which may cause real anguish to witnesses and victims; or the trial must be commenced against the defendants who appear and not the defendant who has absconded. This may confer a wholly unjustified advantage on that defendant. Happily, cases of this kind are very rare. But a system of criminal justice should not be open to manipulation in such a way.»

In a pertinent English case, the accused did not show up on the third day of the hearings and his counsel withdrew. The Court found that this was on purpose, and moreover two prosecution witnesses were foreigners in a case involving conspiracy and theft at the London Heathrow Airport, so it was impossible to guarantee there would still be there to testify if the court adjourned (R v O’Nione, 1986). 
In Republic v Uddin (2017) the Nicosia Assizes Court went into great lengths and a full exposition of authorities previously used, in a case of organized use and exploitation of illegal immigrant workers involving multiple defendants, where one of the Bangladeshi defendants suddenly did not show up, having been released on bail, and the warrant was not executed. The decision is a very good example of how cautious the judges are in this regard.

\subsection{Protection of vulnerable persons}

Cyprus law prior to the implementation of the Directive provided certain procedural safeguards for vulnerable persons suspected or accused in criminal proceedings. According to Article 30(2) of the Constitution, which reprises Article 6(1) of the European Convention on Human Rights, "the press and public may be excluded from all or part of the trial by decision of the court, where ... the interests of juveniles or the protection of the private life of the parties so require, or to the extent strictly necessary in the opinion of the court in special circumstances where publicity would prejudice the interests of justice.

\section{Transposition of Directive (EU) 2016/343 into Cyprus law}

The transposition of the Directive 2016/343 into Cyprus law did not change any of the pre-existing principles of Cyprus criminal procedure. In parliamentary debates, the Law Office of the Republic took the position that the new provisions affirmed the existing constitutional principles, as elaborated further in case law, and dealt with the specificities in the application of these constitutionally- and case-law prescribed presumptions and rights (House of Representatives, 2018). There has so far been no instance of having to apply the new provisions, nor any contrary opinions in our interviewees, so there is little reason to question this position, but only time will tell.

\subsection{Presumption of innocence and its corollary rights}

In terms of formal legislative change, a major one has been the promulgation of statutory provisions, just below Article 3 of the Criminal Procedure Law, which reaffirm the presumption of innocence principle (Art $3 \mathrm{~A}),{ }^{3}$ and the right to silence and to non-selfincrimination (Art 3C) ${ }^{4}$ These provisions essentially replicate the respective provisions of the Directive, i.e. Arts 7 respectively. Even in the few instances where a different word has been used in the Greek text of the statute than in the Greek version of the Directive, there is no difference in meaning. A technical difference in the implementing legislation is that, unlike Article 7 of the Directive, Cyprus has opted to define legislatively what the right not to incriminate oneself consists of, in Art. $3 \mathrm{C}(2)(\mathrm{b})$. That provision, however, replicates the definition of the Directive's Recital 25.

A corollary amendment has been the one of the Rights of Suspect Persons, Arrested Persons and Persons Held in Custody Law 2005: Article 3, which elucidates the content 
of the arrested persons" "right to information and communication with an advocate and relatives", now includes the right to non-self-incrimination among the facts and rights of which the arrested person must be informed by the police upon his or her arrest (the violation of which shall incur, among other penalties, civil liability against the Republic and individuals: Art 36). In fact, the more serious change - symbolical but with long-term consequences - has been the

Beyond that, which falls more into "best practice" territory than actual change in the law, these implementing provisions are not brining anything new to the legal system - nor are they perceived by anyone as doing so. This explains why there was not much discussion about them during the implementation process. In the medium to long term, the conceptual framework may be altered in two ways. First, whereas up to now the Constitution was the starting point of the doctrinal discussion, now statute takes up that role. Second, in the existing doctrinal discourse the right to silence and not to incriminate oneself were treated as an integral aspect of the presumption of innocence (Paraskevas, 2015) but now they may start being treated more distinctly. One must also consider that, Article 3 being an interpretation clause (default incorporation of English criminal procedure law and practice in Cyprus), these are the first substantive provisions of the entire Code. So in the long run these new provisions will revitalize the doctrine of criminal procedure in practice.

\subsection{Public references to guilt}

In contrast to Articles $3 \mathrm{~A}$ and $3 \mathrm{C}$, there was some discussion as to the sibling provision of Article 3B ("Public statements of a public authority"), which implements the Directive's Article 4 ("Public references to guilt"). ${ }^{5}$ Article 3B(1) essentially replicates the first sentence of the Directive's Article 4(1). Art 3B(2) implements the second sentence of the Directive's 4(1) in a way corresponding to the peculiarities of the Cyprus legal system. A lengthy Art $3 \mathrm{~B}(3)$ attempts to regulate in detail what may or not be included in the statutory prohibition and by whom: definitions of "public authority" and "public statement of public authority" follow the definitions of the Directive's Recital ; definitions of "officer", "office or function or position" try to bridge the Directive's conceptual framework with the one in Cyprus and include a long list of officers and offices (from the President of the Republic to contract workers providing service to a government service!). Notable - and telling - is the absence from the list of the House of Representatives (especially if one considers the Konstas v Greece case, in which it were statements by cabinet members in parliament that led to the condemnation of Greece). The original Bill actually included the President (Speaker) and members of the House of Representatives in the list, but the reference was stricken down in the committee stage in parliament (House of Representatives, 2018). 


\subsection{Right to be present and trials in absentia}

On the contrary, there was no legislative action with regard to trial in absentia. As was previously explained, trial in absentia is a very rare phenomenon in Cyprus criminal justice, but the courts do have the power to decide to thus proceed. The original Bill, as prepared by the Law Office of the Republic, included a provision allowing trial in absentia provided the two conditions set out in Article 8(2) of the Directive were met. In a memorandum submitted to the legislature, the Supreme Court objected by noting that such a provision would effectively eliminate the court's discretion. Such discretion is of common-law origin and is exercised with great attention and restraint, as the court's duty is to secure a fair trial: existing case law has achieved the necessary balancing between the accused person's right to be present and the general public interest of concluding trials within reasonable time, by establishing a number of factors to be taken into account. The legislature decided to omit this provision "so that the case law of Cypriot courts, which regulates adequate the court's pertinent authority, may continue to apply" (House of Representatives, 2018).

There is truth in this statement. Cyprus courts have been truly very cautious in exercising their jurisdiction in absentia, but they are jealous of guarding their discretionary power to exercise jurisdiction in extreme circumstances. The idea of such discretion meaning from the courts' inherent powers under the common law tradition finds much resonance. It is likely that an express provision replicating the Directive's conditions will have the opposite effect, i.e. that judges would feel compelled to try cases even in absentia more frequently than under the pre-existing regime. ${ }^{6}$

\section{Conclusion}

Compared perhaps to other, larger, Member States, Cyprus appears to have been in better shape prior to the introduction of the Directive. As a result, the Directive's legislative implementation proceeded relatively smoothly. Cyprus introduced new general provisions on the right to silence and not to incriminate oneself, which replicate the Directive's provisions but also affirm constitutional principles elaborated by the case law of the Supreme Court of Cyprus and supported by the European Convention on Human Rights. With regard to trials in absentia, it was decided that the existing common-law regime may actually be more protective of accused persons than a more formal legislative system and thus serve better the purpose of the Directive.

This state of affairs may be attributed in part to Cyprus criminal procedure following the English common law legal tradition, which adopts the system of adversarial criminal trial and places strong emphasis on the accused being present in order for the Court to obtain jurisdiction over an accused person. Cyprus is a relatively young jurisdiction but its judiciary and the legal profession have been imbued with a sense of the vitality of procedural due process. Moreover, unlike some common-law jurisdictions that place legal or financial barriers to appeal, in Cyprus appeal is readily available to the Supreme Court. 
Another important factor probably has to do with the fact that Cyprus is a small jurisdiction, in terms of both territory and population, with a relatively compact judicial system (and police). The population had been relatively homogeneous (which meant that the social distance between the professional elite that sits in or pleads before appellate courts and the usual suspects was not as great as in other places) and procedural abuses were relatively easy to spot and correct. Things have been of course changing, and the massive flows of lower-income immigrants from both EU Member States and third countries is beginning to challenge the system. As a result, the formal legislative enactment of the constitutional principles further elaborated by the case law comes at a very opportune time.

\section{Notes:}

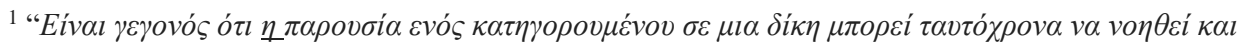

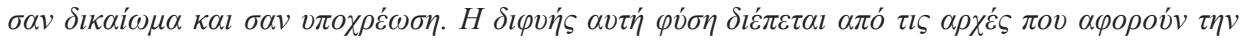

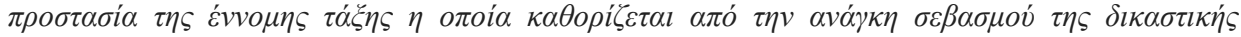

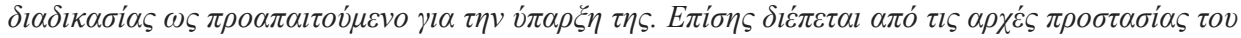

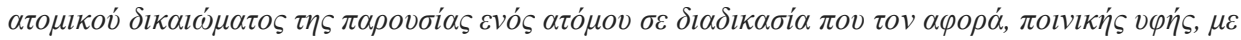

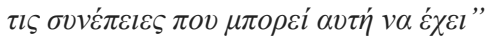

2 The following passage from the opinion of Williams J.

It will thus be seen that in my opinion in all cases whether of felony or misdemeanor, whether the accused be on bail or in custody, whether he be represented by counsel or not, he has a right to be present, subject only to one qualification, and that is, that he does not abuse that right. If he abuses that right for the purpose of obstructing the proceedings of the Court by unseemly, indecent, or outrageous behaviour, the Judge may have him removed and proceed with the trial in his absence, or he may discharge the jury, but subject to that qualification the right of being present remains with the accused as long as he claims it. When he waives it, then the discretion of the Judge comes into play. To take an extreme case by way of illustration: Suppose an accused person to be out on bail, to appear and take his trial for either a felony or misdemeanor, and that when his trial comes on he is found to have absconded. By so doing, I take it, the accused has clearly waived his right to be present, and the Crown might elect to go on with the trial in the prisoner's absence, but then the presiding Judge has to exercise his discretionary power; if in such a case the accused was not represented by counsel in Court, or even if he were so represented, his presence was necessary for the proper conduct of his defence by his counsel, the Judge would, I apprehend, certainly exercise his discretion by postponing the trial. In short, it seems to me that the Judge's discretion is very much at the root of the whole matter, subject to the accused's right, when he has not forfeited the right, does nothing to forfeit it, or does not waive it, to be present " ".

${ }^{3}$ The provision is as follows:

A $\rho \theta \rho o$ 3A [

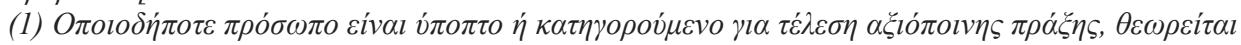

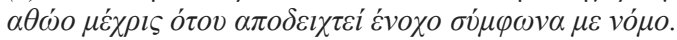

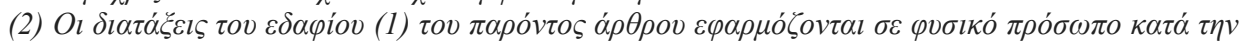

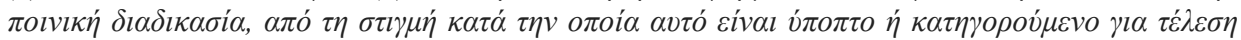

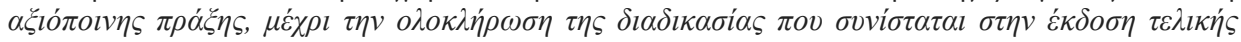
$\delta \imath \kappa \alpha \sigma \tau \imath \kappa \eta \dot{\varsigma} \alpha \pi \dot{\varphi} \varphi \alpha \sigma \eta \varsigma$.

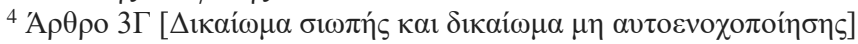

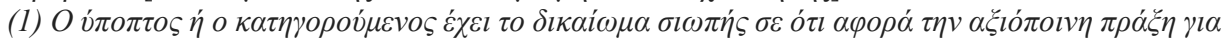

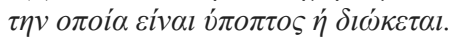




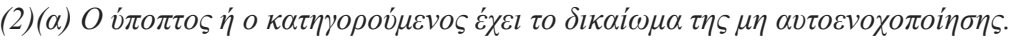

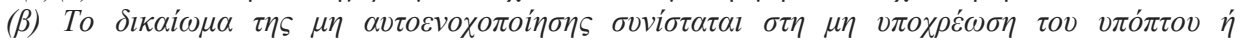

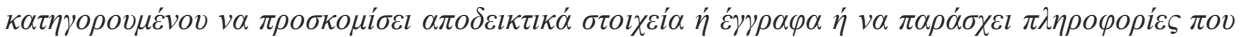

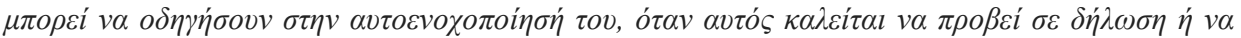
$\alpha \pi \alpha \nu \tau \dot{\eta} \sigma \varepsilon l \sigma \varepsilon \varepsilon \rho \omega \tau \dot{\sigma} \sigma \varepsilon l \varsigma$.

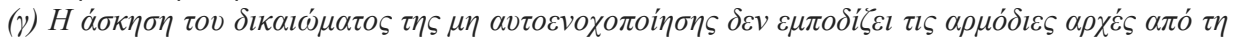

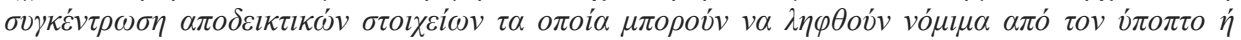

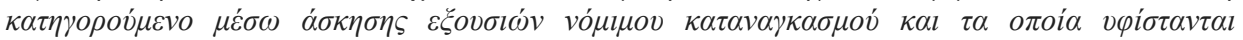

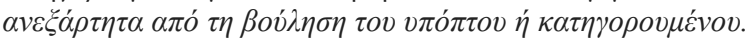

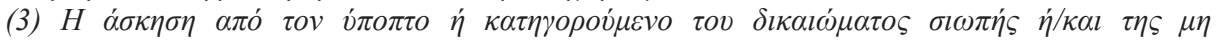

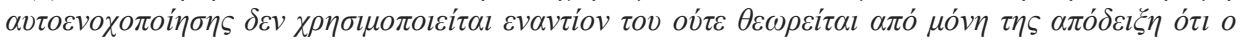

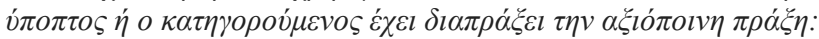

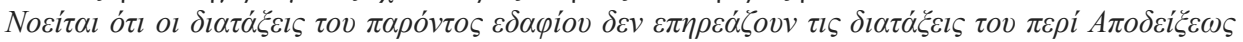

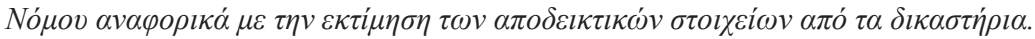

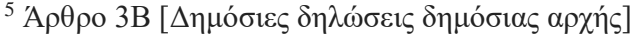

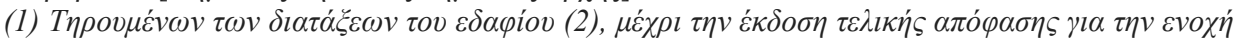

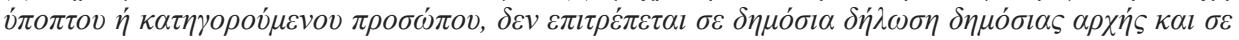

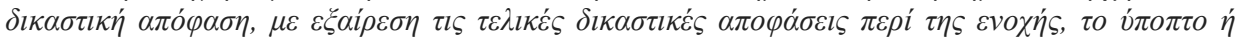

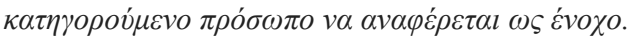

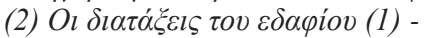

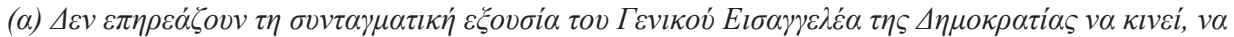

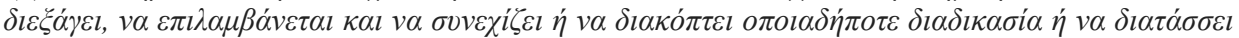

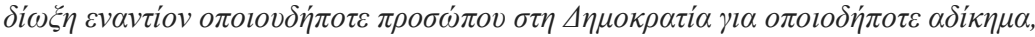

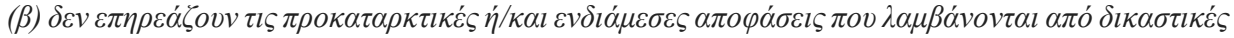

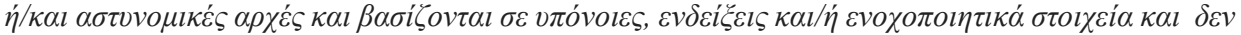

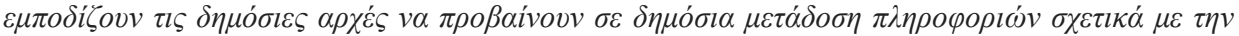

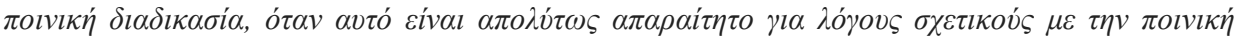

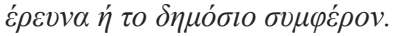

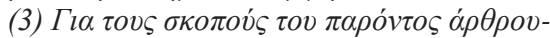

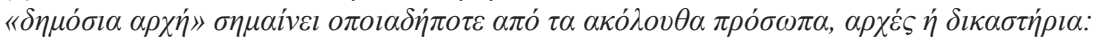

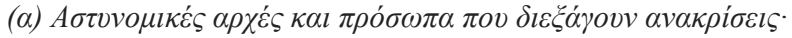

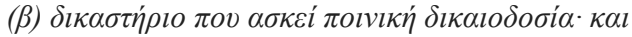

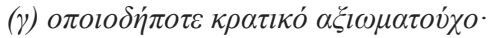

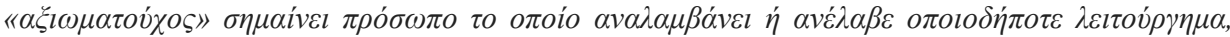
$\alpha \xi \grave{i} \omega \mu \alpha \dot{\eta} \theta \dot{\varepsilon} \sigma \eta$.

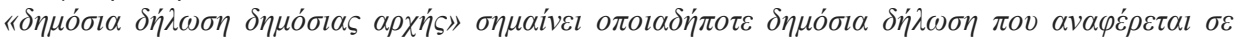

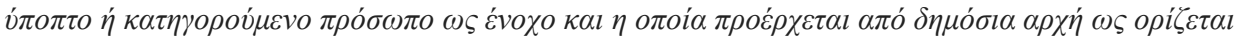

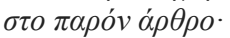

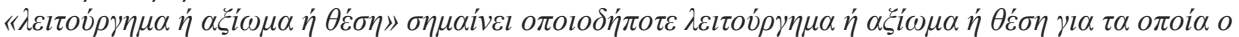

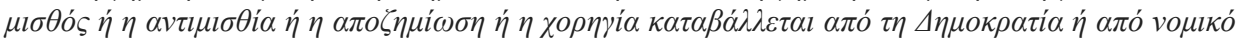

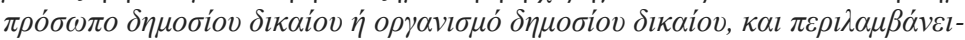

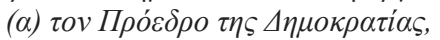

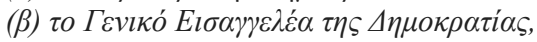

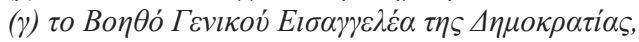

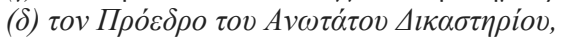

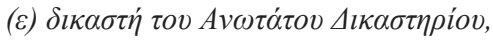

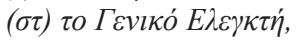

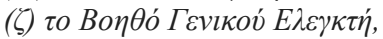

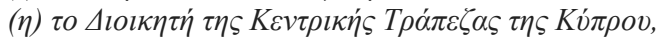




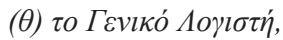

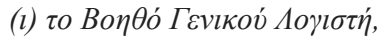

(la) Yлочрүó,

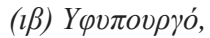

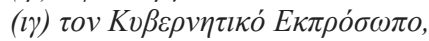

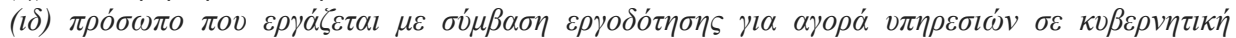

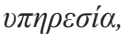

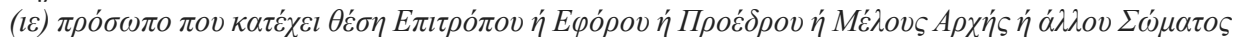

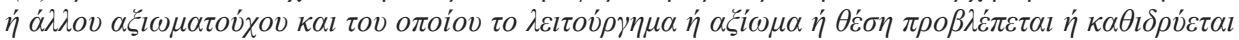

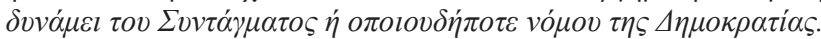

6 This assumption is confirmed both by interviews with experienced members of the legal profession and by the analysis of judicial behaviour of at least one author of this study.

\section{References:}

\section{Case Law}

Supreme Court of Cyprus

Andrrea "Psyllas" v Republic (2003) 2 AA $\triangle 353$

Attorney-General v Spanias (1993) 2 AAD 384

Charalambous v. The Police, (1974) 2 CLR 67

Costis Panayi Kefalos v. The Queen, 19 C.L.R. 121

Georgiou v Fytoria Solomou Ltd (2015) 2 AAD

Gregoriou v Registration Board of Real Estate Agents (2016) 2 AAD

Kirkos v Cyprus Securities Commission (2006)

Kyriakides v Lumian Ltd (2000) 2 AAD 343

Merthodja v. Police (1987) 2 C.L.R. 227

Nikolaides $v$ Police (1999) 1 AAD 551

Parpas v. Republic (1988) 2 C.L.R. 5

Police v. Chrysanthou, 15 C.L.R. 50

President of the Republic $v$ House of Representatives (1994) 3 AA $\Delta 1$

Republic v Avraamidou (2004) 2 AA $\triangle 51$

Republic v Demetriades [1973] 2 C.L.R. 289

Socratis, alias Kokkalos v. The Police (1967) 2 CLR 26

Stamataris And Another v Police (1983) 2 C.L.R. 107

Yannidis v Police (2002) 2 AA $\Delta 143$

Assizes Court

Republic v Uddin ECLI:CY:KDLEF:2017:B

English case law

$R$ v. Abrahams (1895) 21 V.L.R. 343

R. v. Jones (R.E.W.) (No. 2) (1972) 2 All E.R. 731

R. v. O'Nione (1986) Crim. L.R. 342 (C.A.)

European Court of Human Rights

Allen v. United Kingdom, No. 18837/06, 30/03/2010

Colozza v. Italy, No. 9024/80, 12/02/1985

Duda v. Poland, No. 67016/01, 19/12/2006

E.M.K. v. Bulgaria, 2005, No. 43231/98, 18/01/2005

Farhad Aliyev v. Azerbaijan, No. 37138/06, 09/11/2010 
Grauzinis v. Lithuania, No. 37975/97, 10/10/2000

Konstas v Greece, 53466/07, 25/5/2011

Korchagin v. Russia, 19798/04, 1/9/2006

Lala v. the Netherlands, No. 14861/89, 22/09/1994

Mamedova v. Russia, No. 7064/05, 01/06/2006

Medenica v. Switzerland, No. 20491/92, 14/06/2001

Sanader v. Croatia, No. 66408/12, 12/02/2015

Sejdovic v. Italy, No. 56581/00 [GC], 01/03/2006

Stoichkov v. Bulgaria, No. 9808/02, 24/03/2005

T.W. v. Malta, No. 25644/94, 29/04/1999

Wloch v. Poland, No. 27785/95, 19/10/2000

\section{Bibliography}

In English

Hatzimihail, N. (2017) 'On Law, Legal Elites and the Legal Profession in a (Biggish) Small State: Cyprus' in Butler, P. \& Morrris, C. (eds.), Small States in a Legal World. Berlin: Springer, 213244

Hatzimihail, N. (2015) 'Reconstructing Mixity: Sources of Law and Legal Method in Cyprus' in Palmer, V., Mattar, M., Koppel A. (eds.), Mixed Legal Systems, East and West. Ashgate, 75100

Hatzimihail, N. (2013) ‘Cyprus as a Mixed Legal System’ Journal of Civil Law Studies 6 (1), 3796

Kyprianou, D. (2010) The Role of the Cyprus Attorney General's Office in Prosecutions: Rhetoric, Ideology and Practice. Berlin: Springer

Langbein, J.H. (2003) The origins of Adversary Criminal Trial. Oxford: Oxford University Press

Loizou A.N. \& Pikis, G.M. (1975) Criminal Procedure in Cyprus. Nicosia

In Greek

House of Representatives (2018) Report of the Parliamentary Committee on Legal Affairs o $\mathrm{n}$ the Bills "Criminal Procedure (Amending) Law 2018" and "Rights of Persons Arrested and Held in Custody (Amending) Law 2018". Available at: http://www2.parliament.cy/parliamentgr/008_5h/008_05_5335.htm (Accessed: 31 October 2018)

Papacharalambous, Ch. (2015) Cyprus Criminal Law: . Athens: Nomiki Bibliothiki.

Paraskeva, C. (2015) Cyprus Constitutional Law: Fundamental Rights and Freedoms. Athens: Nomiki Bibliothiki

Pikis, G.M. (2013). Criminal Procedure in Cyprus, 2nd ed. Nicosia

Satlanis, Ch. (2012) Introduction to the Cyprus Criminal Process. Athens: Nomiki Bibliothiki

Satolias, C.E. (2017) Introduction to Cap. 155. Nicosia 